\title{
TECHNOLOGY OF E-GOVERNMENT ACCEPTANCE ANALYSIS ON ELECTRONIC RESIDENT IDENTIFICATION CARD (E-KTP) ADOPTION
}

\author{
Oleh, \\ Agustina Dias Kartikasari Algunto (agustinadias23@gmail.com) \\ Jaryono (jaryono@ hotmail.com) \\ Daryono (daryono_jvc@yahoo.com) \\ Faculty of Economics and Business \\ Universitas Jenderal Soedirman
}

\begin{abstract}
The aim of this study is to analyze the effects of Technology Readiness Index (TRI) toward Technology Perceptions that will determine the Actual Usage of e-KTP adoption by taking of 50 people which is the all the population as the respondents. This study investigates the relationship between the personality dimensions of TRI (Technology Readiness Index) and the system specific dimensions of TAM (Technology Acceptance Model). Multiple regressions was used to test the relationship between the dimensions of TRI and TAM. The results show that Optimism influence perceived usefulness and perceived ease of use. Innovativeness and Discomfort influence perceived ease of use. Further, perceived usefulness and perceived ease of use has a significant positive influence on actual usage.
\end{abstract}

Keywords: Technology Readiness Index, Technology Acceptance Model, e-government, e-KTP, public service, technology innovation.

\begin{abstract}
ABSTRAKSI
Tujuan dari penelitian ini adalah untuk menganalisis pengaruh Index Kesiapan Teknologi (Technology Readiness Index/TRI) terhadap persepsi teknologi yang akan menentukan adopsi penggunaan aktual e-KTP dengan menggunakan 50 orang penduduk sebagai responden. Studi ini meneliti hubungan antara dimensi kepribadian TRI dan dimensi sistem spesifik TAM (Technology Acceptance Model). Regresi digunakan untuk menguji hubungan antara dimensi TRI dan TAM. Hasil penelitian menunjukkan bahwa optimisme mempengaruhi kegunaan dan kemudahan penggunaan. Inovasi dan ketidaknyamanan mempengaruhi persepsi kemudahan penggunaan. Selanjutnya, kegunaan dan kemudahan penggunaan memiliki pengaruh positif yang signifikan pada penggunaan aktual.
\end{abstract}




\section{Performance - Vol.22 No.2 September 2016}

Kata kunci: Indeks Kesiapan Teknologi, Technology Acceptance Model, e-government, e-KTP, pelayanan publik, inovasi teknologi.

\section{INTRODUCTION}

Technology revolutions have altered the perspective in performing various activities, and one of which is on the activities of government agencies. Therefore an agency requires an information system that supports the needs of government agencies in creating efficiency and effectiveness as well as in improving services to the public (Mulyo, 2011).

Based on Presidential Instruction No. 3 in 2003 structuring the management system and work processes within the government through e-government development is done by optimizing the utilization of information technology. According to Sathanand Patil et al, (2013), the government to e-government transition process offers governments an opportunity to increase not only their operational transparency, clarity of purpose and responsiveness to citizens, but also their own internal efficiency and effectiveness.

One attempt in the adoption of eGovernment is the implementation of National Identity Card based on Population Identification Number or Nomor Induk Kependudukan (NIK), which is realized through the Electronic Identity Card or e-KTP as a replacement for conventional KTP that existed before.

In its implementation e-KTP card is proven to have limitations in terms of the unpreparedness of the public officer in receiving e-KTP program. Then the main goal of e-KTP which is to facilitate the public activities has not been reached.

The previous studies have measured the adoption of e-government services using technology acceptance theories and models, such as Fishbein \& Ajzen in 1975 who formulated the Theory of Reasoned Action (TRA), In 1985 Fred Davis proposed the Technology Acceptance Model (TAM), the Theory of Planned Behavior (TPB) (Ajzen, 1985), and the Unified Theory of Acceptance and Use of Technology (UTAUT) (Venkatesh, Morris, Davis, \& Davis, 2000). These studies have identified a number of factors that determine the adoption of ICT, such as perceived usefulness, perceived ease of use, and their influence toward actual usage. However, an inclusion of actual use in the integrated model has not yet been proposed.

Godoe \& Johansen (2012) included technology readiness as an antecedent of perceived usefulness and perceived ease of use in TAM. Individual's personality influences the potential acceptance of technology in general. Esen \& Erdoğmuş (2014), Walczuch et al., (2007), and Godoe \& Johansen (2012) found technology readiness has indirectly affected actual usage of the system. 
Technology readiness can be viewed as a gestalt resulting from four personality dimensions: optimism, innovativeness, discomfort, and insecurity. Previous researchers found that Optimism and innovativeness have positive relation on technology acceptance determinants while discomfort and insecurity found to be negatively related to technology acceptance determinants.

This study focus to assesses the adoption of e-government system on eKTP publication acceptance in Department of Population and Civil Registration in Tegal Regency by examining the Technology Readiness Index that has positive relation to technology acceptance model as the antecedent and recommend steps to improve the adoption and utilization of ICT in public sector organizations in Indonesia in order to provide better service.

\section{PROBLEM FORMULATION}

1. Whether there is any positive effect of Optimism on Perceived Usefulness?

2. Whether there is any positive effect of Optimism on Perceived Ease of Use?

3. Whether there is any positive effect of Innovativeness on Perceived Usefulness?

4. Whether there is any positive effect of Innovativeness on Perceived Ease of Use?

5. Whether there is any positive effect of Perceived Usefulness on Actual Use?
6. Whether there is any positive effect of Perceived Ease of Use on Actual Use?

\section{RESEARCH OBJECTIVES}

This research aims to:

1. To evaluate the adoption of egovernment system on E-KTP implementation in Department of Population and Civil Registration in Tegal Regency and recommend strategy to improve the adoption and utilization of Technology in Public sector; and

2. To confirm research in Technology Acceptance Model in public sector can be used as a reference material in the field of technology adoption in egovernment service.

\section{HYPOTHESIS DEVELOPMENT \\ Optimism}

Individuals who are optimistic chose to use their time to do activities that enable them to achieve positive impacts, in which giving more effective result than those who are pessimistic. When dealing with new technology, optimism causes a person to think positively to the results obtained and to avoid concerns over the negative results that may arise from the use of new technologies (Walczuch et al, 2006).

People who are optimistic and innovative with reference to technology in general are thought to hold positive attitudes toward new technology and technology use. (Godoe \& Johansen, 2012) Thereby optimism would make a 


\section{Performance - Vol.22 No.2 September 2016}

person more easily experience the usefulness of new technologies and consider new technology is easy to use.

H1: Optimism positively affects Perceived Usefulness of e-government system.

H2: Optimism positively affects Perceived Ease of Use of e-government system.

\section{Innovativeness}

$\mathrm{Lu}$, Yao, and $\mathrm{Yu}$ (2005) found that perceived usefulness and perceived ease of use are strong variables in willingness to adopt technology and innovativeness showing a direct effect on ease of use and usefulness.

Yi et al (2006) also reported that the early users who have a high level of innovation seems to understand the benefits of new technologies so as to feel confident about the results of the use of new technology and do not hesitate to communicate with others.

H3: Innovativeness positively affects Perceived Usefulness of Egovernment system.

H4: Innovativeness positively affects Perceived Ease of Use of Egovernment system.

\section{Discomfort}

Meuter et al. (2003) demonstrated that technology anxiety which similar with discomfort not only has a strong negative effect on adoption of Technologies, but it also has a negative effect on their experience of using Technologies.

According to Godoe \& Johansen (2012), discomfort is not expected to have a negative impact on perceived usefulness. One would expect people to see the main value of a system, regardless of how they handle it. Still, discomfort is expected to affect perceived ease of use.

H5: Discomfort negatively affects Perceived Ease of Use of Egovernment system.

H6: Discomfort does not affect Perceived Usefulness of $E$ government system.

\section{Insecurity}

Feelings of insecurity related to technology are on the other hand associated with ambiguity and low usage (Parasuraman \& Colby, 2001). A perceived lack of security is generally acknowledged to be important and to have contribution to the slow adoption of ecommerce (Hoffman et al., 1999).

Insecurity is also related to the expected benefits of an innovation, or its realization (Ram, 1987 in Liljander et al, 2006).

H7: Insecurity negatively affects Perceived Ease of Use of Egovernment system.

H8: Insecurity negatively affects Perceived Usefulness of Egovernment system. 


\section{Perceived Ease of Use}

Perceived Usefulness is defined as the prospective user's subjective probability using a specific technology will increase job performance, Perceived Ease of Use and Perceived Usefulness will be positively related (Walczuch, 2007.) The positive and significant relationship between perceived ease of use and actual usage was proved by the studies of Davis (1989), Eriksson et al. (2005), Rigopoulos \& Askounis (2007).

H9: There is positive effect of Perceived Ease of Use on Perceived Usefulness

H10: There is positive effect of Perceived Ease of Use on Actual use

\section{Perceived Usefulness}

Perceived usefulness was found to be significant constructs in the eGovernment adoption literature (e.g. Carter \& Belanger, 2004, 2005 Suki \& Ramayah, 2010).

The positive and significant relationship between perceived usefulness and actual usage was proved by the studies of Davis (1989) and Rigopoulos \& Askounis (2007). Therefore in eGovernment technology adoption acceptance, this research tests the following hypothesis:

H11: There is a positive effect of Perceived Usefulness on Actual use

Based on the review the basic theory and research to formulate a framework in this study is as presented in the exhibit below:

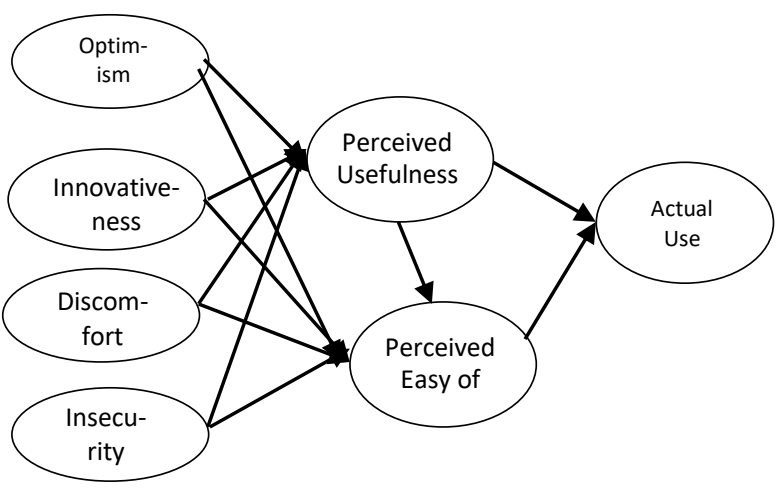

Figure 1 : Research Model

\section{RESEARCH METHODOLOGY}

Data was collected from both of the authorized officer on E KTP publication in Department of Population and Civil Registration, and PATEN officers in each sub-district.

The population of this research is the authorized officers both in the Department of Population and Civil Registry in Tegal Regency as well as patent officers that are in each sub district which are around 50 officers in total. Sampling method employed in this study is Total Sampling.

\section{QUESTIONNAIRE DESIGN}

The questionnaire has 7 sections and 51 questions to measure the actual usage of e government system on electronic resident identification card (e-KTP) in Tegal Regency. The validity testing used is corrected item total correlation. From 
the validity test 3 items was found to be invalid and dropped out from the analysis. H4: Innovativeness positively affects Perceived Ease of Use of E-government system.

Table 1. Questionnaires Source and Validity

\begin{tabular}{|c|c|c|c|}
\hline Variable & Construct & No Item & Source \\
\hline \multirow{4}{*}{ Independent } & Optimism & $\begin{array}{c}1,2,3,4,5,6,7 \\
8,9,10\end{array}$ & \multirow{4}{*}{$\begin{array}{l}\text { Walczuch } \\
\text { et.al. } \\
(2007)\end{array}$} \\
\cline { 2 - 3 } & Innovativeness & $1^{*}, 2,3,4,5,6,7$ \\
\cline { 2 - 3 } Mediating & Discomfort & $\begin{array}{c}1,2,3,4,5,6,7, \\
8^{*}, 10\end{array}$ & \\
\cline { 2 - 3 } & Insecurity & $\begin{array}{c}1,2^{*}, 3,4,5,6, \\
8,9\end{array}$ & \\
\hline \multirow{4}{*}{ Dependent } & $\begin{array}{c}\text { Perceived } \\
\text { Usefulness }\end{array}$ & $1,2,3,4,5,6$ & \multirow{2}{*}{$\begin{array}{c}\text { Davis } \\
(1989)\end{array}$} \\
\cline { 2 - 3 } & $\begin{array}{c}\text { Perceived Easy } \\
\text { of Use }\end{array}$ & $1,2,3,4,5,6$ & $\begin{array}{c}\text { Godoe } \\
\text { and }\end{array}$ \\
& Actual Usage & $1,2,3,4,5,6$ & $\begin{array}{c}\text { Johansen } \\
\text { (2012) }\end{array}$ \\
\hline
\end{tabular}

*invalid

Table 2. Questionnaires source and Reliability

\begin{tabular}{|c|c|c|}
\hline Construct & Cronbach & Source \\
\hline Optimism & 0.815 & \multirow{4}{*}{$\begin{array}{l}\text { Walczuch } \\
\text { et.al. (2007) }\end{array}$} \\
\hline Innovativeness & 0.719 & \\
\hline Discomfort & 0.929 & \\
\hline Insecurity & 0.766 & \\
\hline $\begin{array}{l}\text { Perceived } \\
\text { Usefulness }\end{array}$ & 0.796 & \multirow{2}{*}{ Davis (1989) } \\
\hline $\begin{array}{c}\text { Perceived Easy of } \\
\text { Use }\end{array}$ & 0.749 & \\
\hline Actual Usage & 0.800 & $\begin{array}{c}\text { Godoe and } \\
\text { Johansen } \\
(2012)\end{array}$ \\
\hline
\end{tabular}

Table 2 depicts that all instruments used in this study had a corresponding Cronbach alpha $>0.70$.

\section{MULTIPLE REGRESSIONS}

Multiple regressions is not just one technique, but a family of techniques that can be used to explore the relationship between one continuous dependent variable and a number of independent variables or predictors (Khorasani \& Zheyun, 2014).

This study tests the relationship between Optimism, Innovativeness, Discomfort, Insecurity, Perceived Usefulness as and Perceived Ease of Use on Actual Usage.

\section{Multiple Regressions Model I}

The first regression was run to determine the relationship between Optimism, Innovativeness, Discomfort, Insecurity and Perceived Ease of Use toward Perceived Usefulness.

Table 3. Result of multiple regressions I

\begin{tabular}{|l|c|c|}
\hline Construct & Coefficient & $\mathrm{p}$-value \\
\hline Optimism & .555 & .002 \\
\hline Innovativeness & .053 & .671 \\
\hline Discomfort & -.050 & .359 \\
\hline Insecurity & -.008 & .937 \\
\hline Perceived Easy of Use & .248 & .049 \\
\hline $\mathrm{R}^{2}$ & & .587 \\
\cline { 3 - 3 } Adjusted $\mathrm{R}^{2}$ & & .540 \\
F-Value & & 12.510 \\
\hline
\end{tabular}

From the table above it is know that only Optimism and Perceived Ease of use that significantly affect Perceived Usefulness ( $p$-value<0.05). Both optimism and perceived ease of use has positive effect it can be seen from the coefficients value which are positive.

The Adjusted R2 indicates that 54\% of Perceived Usefulness was influenced by Optimism, Innovativeness, Discomfort, Insecurity, and Perceived Ease of Use and 
the other $46 \%$ was influenced by unknown variables that are not examined. The $\mathrm{F}$ value indicates that the model is fit $(12.510>2.427)$.

\section{Multiple Regressions Model II}

The second regression was run to determine the relationship between Optimism, Innovativeness, Discomfort, and Insecurity toward Perceived Ease of Use.

Table 4. Result of multiple regressions II

\begin{tabular}{|l|c|c|}
\hline \multicolumn{1}{|c|}{ Construct } & Coefficient & p-value \\
\hline Optimism & .514 & .008 \\
\hline Innovativeness & .351 & .017 \\
\hline Discomfort & -.135 & .034 \\
\hline Insecurity & -.172 & .144 \\
\hline \multicolumn{2}{|c|}{$\mathrm{R}^{2}$} & .534 \\
Adjusted $\mathrm{R}^{2}$ & & .493 \\
F-Value & & 12.897 \\
\hline
\end{tabular}

From the table above it is know that Optimism, Innovativeness and Discomfort have significant effect on Perceived Ease of Use (p-value<0.05). From the coefficient values Both optimism and Innovativeness have positive effect while Discomfort has negative effect.

The Adjusted R2 indicates that $49.3 \%$ of Perceived Ease of Use was influenced by Optimism, Innovativeness, Discomfort, Insecurity, and the other $50.7 \%$ was influenced by unknown variables that are not examined. The $\mathrm{F}$ value indicates that the model is fit $(12.897>2.579)$.

\section{Multiple Regressions Model III}

The third regression was run to determine the relationship between Perceived Usefulness and Perceived Ease of Use toward Actual Usage.

Table 5. Result of multiple regressions III

\begin{tabular}{|c|c|c|}
\hline Construct & Coefficient & p-value \\
\hline Perceived Usefulness & .930 & .000 \\
\hline Perceived Easy of Use & .334 & .043 \\
\hline $\mathrm{R}^{2}$ & & .609 \\
\cline { 3 - 3 } Adjusted $\mathrm{R}^{2}$ & & .592 \\
\cline { 3 - 3 } F-Value & & 36.545 \\
\hline
\end{tabular}

From the table above it is know that both Perceived Usefulness and Perceived Ease of have significant effect on Actual Usage ( $p$-value<0.05). Both Perceived Usefulness and perceived ease of use has positive effect it can be seen from the coefficient values which are positive.

The Adjusted R2 indicates that $59.2 \%$ of Perceived Usefulness was influenced by Perceived Usefulness and Perceived Ease of have and the other $40.8 \%$ was influenced by unknown variables that are not examined. The $\mathrm{F}$ value indicates that the model is fit $(12.510>3195)$.

\section{CONCLUSION}

The result of this study shows which one is a main factor to influence the implementation to e-government in e-ktp system adoption. Furthermore, the government can find out the solutions to increases the effectiveness and efficiency of e-ktp system by paying attention on the employee readiness. 


\section{Performance - Vol.22 No.2 September 2016}

There factors that can influence the level of employee readiness to use e-ktp system are:

1. Optimism

2. Innovativeness

3. Discomfort

4. Perceived Ease of use

5. Perceived Usefulness

This study found that perceived usefulness plays an important role to influence the actual usage of egovernment system specifically on e-ktp system adoption among the employee of Government can focus more to the perceived usefulness of e-ktp system to increase actual usage of e-ktp system. The second main factor is perceived ease of use. Therefore, the government has to focus to the perceived ease of use of e-ktp system so it's important to make the system as simple so the employee would not be confused.

And the factors that boost the perceived usefulness and perceived ease of use is the level of technology readiness of the employee. Optimism plays an important role to influence perceived usefulness and perceived ease of use so the government can conduct training or workshop to encourage the employee to use e-government system. Other aspect like innovativeness and discomfort also influence perceived ease of use so the government can make a program to stimulate the employee to be more innovative not only about the egovernment system but the overall concept of technology so they can face their discomfort feeling toward technology. When an employee is ready to accept e-ktp system they can work more effectively and efficiently, thus would avoid mistake like the misprint of e-KTP (wrong name or date of birth) and can reduce the waste of e-KTP form.

\section{REFRENCE}

Lagos, Nigria. Journal of Economics and Finance. pp. 1-12.

Ajzen, I., \& Fishbein, M. (1975). Understanding attitudes and predicting social behavior. Englewood Cliffs, N J: PrenticeHall

Ajzen, I. (1985). From Intentions to actions: A theory of planned behavior. In J. Kuhl, \& J. Beckmann (Eds.), Action control: From cognition to behavior. New York: Spinger-Verlag

Akintunde, N., A. 2012. Path Analysis Step by Step Using Excel. Journal of Technical Science and Technologies, 1(1):9-15

Alchindi, D., Q, Larasati, E., Rihandoyo. 2013. Analisis Kualitas Pelayanan Pembuatan E-KTP di Kecamatan Pedurungan. Jurnal Administrasi Publik.

Burgelman, RA., Maidique, A.\& Wheelwright, SC. (2001). Strategic Management of Technology and Innovation. New York: McGrawHill.

Burton-Jones, A., \& Hubona, G. S. (2006). The mediation of external variables in the technology acceptance model. Journal of 
Information \& Management. Vol. 43

Cheng San, A., N., \& Yee, C., J. 2013. The Modified Technology Acceptance Model for Private Clinical Physicians: A Case Study in Malaysia, Penang. International Journal of Academic Research in Business and Social Sciences. Vol. 3 No. 2

Chuttur M.Y. 2009. Overview of the Technology Acceptance Model: Origins, Developments and Future Directions. Indiana University, USA. Sprouts: Working Papers on Information Systems, 9(37). http://sprouts.aisnet.org/9-37

Davis, F., D. (1985). A technology acceptance model for empirically testing new end-user information systems: theory and results. Unpublished Doctoral dissertation.

Davis, F., D. (1989). Perceived usefulness, perceived ease of use, and user acceptance of information technology. MIS Quarterly. Vol. 13 No. 3

Eriksson, K., Kerem, K., \& Nilsson, D. 2005. Customer Acceptance of Internet Banking in Estonia. International Journal of Bank Marketing. Vol. 23

Esen, M., \& Erdoğmuş, N. (2014). Effects of Technology Readiness on Technology Acceptance in E-HRM: Mediating Role of Perceived Usefulness. The Journal of Knowledge Economy \& Knowledge Management, Vol. 9.
Evans, D. W., 1990. People Communication and Organization. London: Pitman Publication.

Fang, Zhiyuan. E-Government in Digital Era: Concept, Practice, and Development. International Journal of The Computer, The Internet and Management. Vol. 10 No.2

Gakunu, P. (2004). The status of ICTs and their utilization in Kenya. A statement on policy reforms in the cabinet Office.

Godoe, P., \& Johansen, T. S. (2012). Understanding adoption of new technologies:Technology readiness and technology acceptance as an integrated concept. Journal of European Psychology Students , Vol.3.

Gyaase, P., Sarfo, A. A., \& Bediako, Y. (2013). The Adoption Of Information And Communication Technology In The Public Sector; A Study Of The Financial Management In The Ghana Education Service (GES). International Journal of Scientific \& Technology Research, Vol. 2 Issue 12.

Hermana, B., et al. 2012. E-Government Implementation in Indonesia: Financial Transparency on the Web. International Conference on eEducation, e-Business, eManagement and e-Learning.

Hoyle, R. H. (1995). The structural equation modeling approach: Basic concepts and fundamental issues. In Structural equation modeling: Concepts, issues, and applications, 


\section{Performance - Vol.22 No.2 September 2016}

R. H. Hoyle (editor). Thousand Oaks, CA: Sage Publications, Inc.,

Hu, L., \& Bentler, P., M. 1999. Cutoff criteria for fit indexes in covariance structure analysis: Conventional criteria versus new alternatives. Structural Equation Modeling: A Multidisciplinary Journal. Vol. 6 Issues 1

Jhonston, R., \& Clark, G. (2005). Service Operation Management: Improving Service Delivery. Edinburg: Prentice Hall.

Jonathan, Sarwono. 2006. Metode Penelitian Kuantitatif dan Kualitatif. Yogyakarta : Graha Ilmu

Kamath, V., Rodrigues, L. L. R., \& Desai, P. The Role of Top Management in Using Knowledge Management as a Tool for Innovation - A System Dynamics Perspective. Proceedings of The World Congress on Engineering

Karnova, D., \& Maryani. 2014. Implementasi E-Government Dalam Penyelenggaraan E-KTP. Jurnal Administrasi Pembangunan, Vol. 2 No. 3.

Kumar, V., Mukerji, B., Butt, I., Persaud, A. 2007. Factors for Successful eGovernment Adoption:

a Conceptual Framework. The Electronic Journal of e-Government. Vol. 5

Kumar, S. A., \& Suresh, N. 2009. New Age: Operation Management. New Delhi: New Age International.

Kothari, C., R. 2004. Research Methodology: Methods and Technique. New Delhi: New Age International Limited
Mahmood, Z., Amir, A., Javied, S., \& Zafar, F. (2013). Strategic Management of Technology and Innovation. Global Journal of Management and Business Research , Vol. 13 Issues 12

Mak, Stephen. 2001. An Enabling IT Architecture and Infrastructure to Support e-government. Government Through The Portal Conference.

Patil, S., \& Kulkarni, M. (2013). Technologies used for Egovernment Integration: A Survey. International Journal of Emerging Technology and Advanced Engineering, Vol 3 Issues 5.

Porter, C., E., \& Donthu, N. 2006. Using the technology acceptance model to explain how attitudes determine Internet usage: The role of perceived access barriers and demographics. Journal of Business Research. Vol. 59

Parasuraman, A. 2000. Technology readiness index (TRI): A multipleitem scale to measure readiness to embrace new technologies. Journal of Service Research, 2, 307- 320.

Parasuraman, A., \& Colby, C. L. 2001. Techno-ready marketing: How and why your customers adopt technology. New York: Free Press.

Park, S. Y. (2009). An Analysis of the Technology Acceptance Model in Understanding University Students' Behavioral Intentionto Use eLearning. Educational Technology \& Society, 12 (3), 150-162.

Phichitchaisopa, N., \& Naenna, T. 2013. Factors Affecting The Adoption of 
Healthcare. EXCLI Journal , Vol. 12.

Reigeluth, C.M. 1994. The imperative for systemic change. In C.M. Reigeluth \& R.J. Garfinkle (Ed.), Systemic Change in Education. Englewood Cliffs, NJ: Educational Technology Publications.

Rigopoulos, G. \& Askounis, D. 2007. A TAM Framework to Evaluate User's Perception Toward Online Electronic Payments. Journal of Internet Banking and Commerce. Vol. 12

Robot, P., I. 2013. Implementasi Kebijakan Pelayanan E-KTP di Kecamatan Amurang Barat Kabupaten Minahasa Selatan. Articles of Governance. Vol 5 No 1

Safeena, R., Kammani, A. 2013. Conceptualization of Electronic Government Adoption. International Journal of Managing Information Technology (IJMIT). Vol.5 No.1

Schepers, J., \& Wetzels, M. 2007. A meta-analysis of the technology acceptance model: Investigating subjective norm and moderation effects. Information \& Management, 44, 90-103.

Sekaran, Uma. 2003. Research Methods for Business: A Skill Building Approach. Southern Illionis: John Wiley \& Sons, Inc

Sharma, S., K., \& Chandel, J., K. 2013. Technology Acceptance Model for the Use of Learning Through Websites Among Students in Oman. International Arab Journal of eTechnology. Vol. 3 No. 1
Slamet Mulyo, 2011. Jurnal "Enkripsi RC4 sebagai Security pada Database Aplikasi SIAK.

www.mercubuana.ac.id

Sugiyono. 2007. Metode Penelitian Kuantitatif Kualitatif dan R\&D. Bandung: Alfabeta

Suhr, Diana. 2008. Step your way through Path Analysis. WUSS 2008 Educational Forum and Conference

Sukaatmadja, P. G., Ratnaningrum, L. P., \& Kerti Yasa, N. N. (2014). THE APPLICATION OF Technology Acceptance Model on Internet Banking Users in The City of Denpasar. Journal of Macromarketing, Vol. 16 No. 2.

Suki, N., M., \& Rumayah, T. 2010. User Acceptance of the E Government Services in Malaysia: Structural Equation Modelling Approach. Interdisciplinary Journal of Information, Knowledge, and Management. Vol. 5

Tambouris, E., Gorilas, S., \& Boukis, G. 2001. Investigation of electronic government. [URL: http://www.egovproject.org/egovsite /tambouris_panhellenic.pdf\#search= 'investigation $\% 20 \mathrm{of} \% 20$ electronic $\% 20$ government'].

Venkatesh, V., \& Davis, F.,D. (2000). A theoretical extension of technology acceptance model: four longitudinal field studies. Journal of Management Science. Vol. 46 No. 2

Wahid, Fathul. 2008. Evaluating Focus and Quality of Indonesian EGovernment Website. National Conference on Information and 
Performance - Vol.22 No.2 September 2016

Technology Application. ISBN: 979-756-061-6

Walczuch, R., Lemmink, J., \& Streukens, S. (2007). The effect of service employees' technology readiness on technology acceptance. Journal of Information \& Management. Vol. 44.

Zucker, L., G. 1987. Institutional Theories of Organization. Annual Review of Sociology, vol. 13.

Websites:

e-ktp. (n.d.). Retrieved October 24, 2015, from http://www.e-ktp.com: http://www.ektp.com/2011/05/perbedaan-ktplama-ktp-nasional-ktp-elektronik-e$\mathrm{ktp} /$

e-ktp. (n.d.). Retrieved October 24, 2015, from http://www.e-ktp.com: http://www.e-ktp.com/2011/06/prosespembuatan-e-ktp/

Wikipedia. (n.d.). Retrieved December 7, 2015, from Technology: https://en.wikipedia.org/wiki/Technology

Wikipedia. (n.d.). Retrieved October 20, 2015, from Kartu Tanda Penduduk: https://id.wikipedia.org/wiki/Kartu_ Tanda_Penduduk Total population sampling. (n.d.). Retrieved December 30, 2015, from http://dissertation.laerd.com/: http://dissertation.laerd.com/totalpopulation-sampling.php 